\title{
CATIMBÓ E TORÉ: PRÁTICAS RITUAIS E XAMANISMO DO POVO POTIGUARA DA PARAÍBA
}

\author{
CATIMBÓ AND TORÉ: RITUAL \\ PRACTICES AND SHAMANISM OF THE \\ POTIGUARA PEOPLE IN PARAIIBA
}

\author{
José Glebson Vieira \\ jglebson@gmail.com \\ Professor do Departamento de Antropologia e do Programa de Pós-Graduação em Antropologia Social/UFRN \\ Orcid: https://orcid.org/0000-0002-5546-1846
}

\section{RESUMO}

Este artigo pretende analisar a prática ritual do catimbó e da jurema entre o povo Potiguara, que se localiza no litoral do Estado da Paraíba (Brasil), com o intuito de apontar para a articulação de tais práticas com o ritual do toré, tendo como pano de fundo a concepção nativa de encantado. Os Potiguara definem os encantados como sendo os habitantes de locais específicos como a mata e os fundos e os definem pelo atributo da invisibilidade e por dois predicados específicos: a humanidade e a imortalidade. Em suas práticas rituais, os pajés, os mestres do toré e os especialistas do catimbó acionam entidades espirituais que estão presentes no culto da jurema (como mestres e caboclos), entidades do catolicismo (santos). A centralidade da jurema e a presença de entidades das religiosidades afro-brasileiras em tais práticas propiciam o uso pejorativo do termo catimbozeiro para classificar os especialistas rituais. Esses dialogam com os encantados através de viagens e da incorporação espiritual por meio de melodias, que são chamamentos para "fazer o trabalho", de orações fortes e do uso da defumação com fumo e que estão presentes em maior ou menor expressividade no toré. O toré é concebido e vivido como brincadeira, como ritual e como guerra contra o visível e o invisível, o que remete às operações de tradução, mediação e cura, e indica uma efetiva combinação com novas técnicas disponíveis e as possibilidades de agenciamento de humanos e entidades encantadas e espirituais.

Palavras-chave: Xamanismo. Encantados. Corporalidade.

\begin{abstract}
This paper intends to analyze the ritual practice of catimbó and jurema within the Potiguara people, located on the coast of the State of Paraíba (Brazil), aiming to point out the articulation of such practices with the ritual of toré, having as background the native conception of encantado. The Potiguara define the encantado as the inhabitants of specific places as the forest and the backlands and define them by the attribute of invisibility and by two specific predicates: humanity and immortality. In their ritual practices, the pajés, the master of toré and the specialist of the catimbó trigger spiritual entities that are present in the cult of jurema (such as masters and caboclos), entities of catholicism (saints). The centrality of jurema and the presence of entities of Afro-Brazilian religiosities in such practices provide the pejorative use of the term catimbozeiro to classify
\end{abstract}


the ritual specialists. These specialists dialogue with the encantados through trance trips and/or incorporate them by means of melodies that are called "todo the work". They make use of strong prayers, smoking with tobbaco and other herbs and that are present in a greater or less expressiveness in the rituals that refers to translation, mediation and healing operations, and its uses indicate an effective combination with new techniques available. The toré is conceived and lived as a joke, as a ritual and as a war against the visible and the invisible, referring to the operations of translation, mediation and cure, and it indicates an effective combination with new available techniques and the possibility of agency of humans and enchanted and spiritual entities.

Keywords: Shamanism. Enchanted and corporeality.

\section{QUEM SÃO OS POTIGUARA?}

A população dos Potiguara da Paraíba é de aproximadamente 14.213 pessoas (SIASI / SESAI / MS 2013) e encontra-se distribuída em 38 localidades situadas em três municípios do litoral norte da Paraíba. As aldeias constituem três Terras Indígenas (TIs) contíguas, perfazendo um total de 33.801 hectares: a TI Potiguara (21.238 hectares) que está regularizada, a TI Jacaré de São Domingos (5.032 hectares) que se encontra igualmente regularizada e a TI Potiguara de Monte-Mór (7.530 hectares) que está declarada.

Na Paraíba, sua presença é marcante nos dois municípios litorâneos (Baía da Traição e Marcação) situados no interior de seu território e nas cidades contíguas de Rio Tinto, Mataraca e Mamanguape, bem como na capital do Estado. Das trinta e oito localidades, trinta e duas são consideradas aldeias, em virtude de possuir um representante ou cacique local. Em relação as demais, não há uniformidade na classificação: por vezes, são chamados de "pequeno povoado", um "lugarejo", uma “comunidade", uma "família”, e até mesmo são denominadas como uma "aldeia sem cacique".

A localização dos Potiguara em tais faixas de terras guarda uma estreita relação com os processos históricos dos séculos XVIII e XIX que marcaram a conquista definitiva do território pelos portugueses. Os Potiguara foram reduzidos na Paraíba em dois aldeamentos assistidos pelos missionários do Carmo da Reforma: o aldeamento São Miguel da Baía da Traição no litoral e o da Preguiça localizado cerca de $24 \mathrm{~km}$ da costa.

Na segunda metade do século XVIII, a situação dessas aldeias foi modificada pelo diretório pombalino que determinou a expulsão das ordens missionárias e a elevação das aldeias à categoria de vilas de índios. O aldeamento de São Miguel da Baía da Traição passou a ser chamado de Vila de São Miguel da Baía da Traição e o aldeamento da Preguiça como Vila Nossa Senhora dos Prazeres de Monte-Mór. Provavelmente, é nesse contexto que os Potiguara passaram a associar seu território a um santo padroeiro e a incluir as devoções a São Miguel e à Nossa Senhora dos Prazeres em sua vida cerimonial e, assim, a invocação aos santos católicos assume um lugar importante na religiosidade potiguara e marca o ciclo festivo e cerimonial das aldeias, revelando, por meio das práticas de promessa e de cura e dos ritos comemorativos, momentos específicos de gestão e negociação da alteridade.

\section{REINADOS ENCANTADOS E A NOÇÃO DE PERIGO}

A fim de melhor compreender a prática ritual do catimbó e da jurema e sua articulação com o ritual do toré, torna-se imprescindível partir do enten- 
dimento acerca da concepção nativa de encantado. A visão sobre encantados e encantamentos é importante, na medida em que permite apreender o modo pelo qual os "mestres" ou os chamados "especialistas rituais" atuam na perspectiva de lidar com o mundo não humano, sendo este representado pelos encantados e pelos mundos e lugares onde os mesmos povoam e atuam, como também as entidades do catolicismo.

Concomitantemente, tal visão deve estar articulada a uma ideia já consolidada na literatura etnológica sobre os povos indígenas localizados no nordeste brasileiro, que se refere: ao complexo ritual da jurema (NASCIMENTO, 1994; MOTA; BARROS, 2002) que tende a reunir um complexo e entrelaçado conjunto de ritos, sistemas de classificação e crenças indígenas e africanas que tem na jurema sua centralidade; e a concepção de cosmopolítica, como apresentada por Stengers $(1997,2005)$ e Latour (2004), que tende a revelar os espaços de trânsitos e mediações de pajés, xamãs e mestres que são irredutíveis a um único domínio, seja o humano, permeado pelas relações multilocais, seja o cósmico, emaranhado de relações com agentes sobrenaturais (SZTUTMAN, 2005) e que atuam na construção de mundos (OVERING, 1990).

Os Potiguara descrevem os encantados como sendo os habitantes de locais específicos como a mata e os fundos dos rios e do mar e os definem pelo atributo da invisibilidade e por dois predicados específicos: a humanidade e a imortalidade. Na expressão nativa, eles "não são gente como a gente", mas já foram "gente como a gente". Os encantados correspondem a uma categoria de agentes que assumiram a condição humana, foram "gente como a gente", e foram capturados e familiarizados por uma agência extra-humana.

A passagem compulsória da condição humana para a de encantado, ocorrida, em geral, no período da infância, fez-se a despeito do imperativo da morte, o que os diferencia, num certo sentido, daqueles que passaram por ela. Sobre esse aspecto, registrei diversos relatos de pessoas idosas, em todas as aldeias, que apontaram para o abandono de crianças pagãs no meio da mata e nas margens dos rios e no mangue e de sua captura por animais. Em seguida, elas foram levadas para os reinados ou jardins e se transformaram em encantados.

Essa concepção se assemelha, em alguma medida, ao que Léo Neto (2011) assinala em relação aos encantados para os Atikum, os quais seriam os espíritos dos antigos índios, os "caboclos velhos" que não foram batizados, mas que receberam, a "Força de Santa Madalena com Jesus e o todo poderoso irmão de Luz. Eles não são batizados [sic] mas têm Luz. Eles têm a Luz. São irmão de Luz" (LÉO NETO, 2011, p. 70). Como mostrarei adiante, há relatos de encantados entre os Potiguara que remetem ao abandono de criança pagãs e o acolhimento por animais encantados e também e a ampliação da concepção de encantado, por meio da incorporação dos "irmãos de luz" ao sistema de classificação dos espíritos.

Conquanto os processos de encantamento promovam a passagem da ordem humana para a extra-humana, eles tendem a preservar a humanidade dos encantados, na medida em que estes podem assumir a condição humana por meio da transformação do seu corpo. Nesse sentido, preserva-se a categoria de pessoa, assumindo um corpo que ainda possui sangue correndo nas veias.

A concepção de encantamento relacionada com a não passagem do encantado pela morte indica um esforço, de um lado, em posicioná-lo num gradiente de distintividade em relação a outros espíritos, que povoam as representações nativas sobre o invisível. De um outro lado, o empenho em se situar numa linha tênue de continuidade e de distanciamento em relação aos "índios brabos" do "tempo muito antigo", dos quais os Potiguara se veem como descendentes ${ }^{1}$. 
Essa visão se assemelha a de outro coletivo indígena do nordeste, os Kiriri, como nos informa Nascimento (1994)2. Para os Kiriri, os encantos (também chamados de encantados, mestres encantados, gentios ou caboquinhos) são tidos como entidades sobrenaturais benéficas que se caracterizam por serem vivas, pois não passaram pela morte, não sendo, portanto, espírito de morte "que é coisa de gente branco, numa alusão ao espiritismo, umbanda, ou outros trabalhos que não são coisa de índio" (NASCIMENTO, 1994, p. 13, grifos do autor). Há a crença de que alguns dos encantados tiveram existência humana, depois do que se teriam encantado, passando a residir no reino dos encantados "ou reino da Jurema, ou Juremá, mas sem que tenham morrido. Não deixaram de viver, não são também espíritos desencarnados" (NASCIMENTO, 1991, p. 13). Nesses reinos, eles continuam vivos, mas o acesso a eles só é possível, para os Kiriri, através da ingestão da Jurema.

A definição de encantados para os Kiriri assemelha-se, em alguma medida, com a concepção potiguara, notadamente, no tocante à diferenciação entre encantamento e morte como processos de condução e transposição dos espíritos para lugares encantados e também a associação realizada ao universo mágico-religioso não indígena, aos rituais que lidam diretamente com os espíritos dos mortos, os quais são interpretados e classificados pelos indígenas como sendo parte de sistemas de crenças e de práticas rituais do espiritismo e do catimbó, realizadas por brancos e por negros, respectivamente. Porém, diferenciam-se no que diz respeito à natureza benéfica dos encantados, visto que, entre os Potiguara, há uma variação quanto à potência dos encantados que depende do lugar e do reinado onde vivem.

Os reinados encantados para os Potiguara configuram-se em dois domínios: o do fundo (rios e mar) e o da mata ${ }^{3}$. Para cada um, há um dono, ora chamado de pai ou mãe, ora de dono dos bichos, ou somente de bichos encantados, os quais estão associados a um contexto relacional visto tanto do ponto de vista do perigo, quanto da proteção. De um lado, são acionados gradientes de periculosidade para cada encantado devido ao temor e a imprevisibilidade de suas ações e ao contato por meio de agressões. De outro lado, esses seres invisíveis são concebidos como espíritos protetores da mata, dos animais, dos rios e do mar, com quem as pessoas podem estabelecer relações de troca e simpatia. A concepção de que os encantados atuam como espíritos protetores das águas e das matas está presente entre os Atikum, como assinala Neto (2011).

O reinado das águas e dos fundos é marcado pela suntuosidade e "boa vida". Ele é habitado por animais e dominados pela sereia do mar (mulher cobra) e por uma menina (cabocla ou uma "branca"), que se tornou a mãe dos rios (também chamada de mãe d'água). Apesar da diferença entre o processo de encantamento, elas compartilham a mesma identificação ontológica, pois para os nativos, a mãe do rio é a mesma mãe do mar e vice-versa. Tal semelhança evidencia-se a partir dos mecanismos de sedução direcionados aos humanos, que correspondem à "flechada" ("se agradar" de alguém), bem como da predominância de fartura e abundância no domínio dos reinados, e da preferência por oferendas, que possuam bons odores como perfumes ou óleos e "boa comida". A dona do rio e do mar ouve, é arredia e cismada, suas ações são imprevisíveis, e desenvolveu a capacidade de falar e gosto pelo canto, que é executado, especialmente à noite. É comum a referência à mãe das águas como sendo ora uma cabocla, classificada como sendo uma índia tapuia - que mora abaixo do dendezeiro, cujas preferências alimentares incluem peixes e camarão crus com mel, ora uma "branca" (não-cabocla), que reside nos arrecifes, nas correntes marítimas ou em palácios ou castelos e se alimenta de peixes e outras espécies aquáticas também cruas. A mãe do rio estabelece formas de comunicações ligadas à fala sugerindo uma domesticidade e se situa mais próximas do espaço da 
aldeia, diferenciando-se da mãe do mato, que não possui a habilidade de falar, e moram em locais espacialmente distantes das aldeias.

O reinado da mata é "dominado" pela Cumadre Florzinha (ou mãe/ dona do mato), definida como uma cabocla tapuia ou índia selvagem, cismada e "braba", que aprecia fumo, carne crua com mel e faz uso da amesca $^{4}$ para a defumação de seus animais. Além disso, ela não fala, apenas se comunica por assobios o que lhes confere a posição de rusticidade ou selvageria, estando, portanto, irredutível e indissociável da natureza. As relações (instáveis) entre a Florzinha e o pai do mato (também um tapuio) ocorrem pelo estabelecimento de laços ora de amizade e parcerias, ora de inimizade e disputas. Ao mesmo tempo em que é incluído o papel de protetora do meio ambiente, os Potiguara indicam um tipo de relação com seres não humanos que evidencia uma forma de afirmação da ordem do mundo, baseada na predação ou na apropriação da alteridade alheia. A Florzinha representa uma alteridade radical, pois ocupa a posição de índia selvagem.

Os termos classificadores tapuio, índia selvagem, cismada e braba são utilizados na identificação de aspectos que promovem a marcação de um certo conjunto de seres não humanos vinculados a um passado não necessariamente definido dentro de um tempo histórico, cronologicamente verificável. O uso dos termos sugere ainda o estabelecimento de uma diferenciação entre os indígenas de hoje - "índios civilizados" ou "índios misturados" — com aqueles que são classificados como selvagens, puros, mas com os quais se reconhece um certo de tipo de vínculo simbólico, mas descontínuos do ponto de vista cultural. Face a essa descontinuidade, sempre reiterada pelos indígenas, é possível falar das transformações operadas historicamente que produziram um povo civilizado, múltiplo, heterogêneo ou misturado em sua origem — que contém a diferença cultural - e que pensa sobre si através da alteridade alheia.

A oposição operada pelos Potiguara entre tapuia e caboclos remete ao uso de categorias forjadas no processo colonial, e enquanto tais, existiram como categorias relacionais (CRUZ, 2018), compondo um conjunto de "classificações raciais [que] podem ser pensadas como um artifício, uma ficção legal" (RAPPAPORT, 2015, apud CRUZ, 2018, p. 27). As categorias classificatórias, como sugere Rappaport (2015), eram situacionais no fluxo da vida social, assim como poderiam ser concebidos como "registros de disputas legais e processos administrativos assinalam os indivíduos a uma ou outra categoria, em um processo atravessado pelo poder" (RAPPAPORT, 2015, apud CRUZ, 2018, p. 27).

A classificação de "caboclo" se refere "aos indígenas em estado de domesticidade, que são chamados geralmente 'caboclos', e os que ainda se conservam na vida selvagem, e que são comumente denominados Tapuias' (KOSTER, 1943, apud CRUZ, 2018, p. 23). Para pensar o contexto específico, o dos Potiguara da Paraíba, é importante reiterar o que desenvolvi noutro momento (VIEIRA, 2012), a respeito das narrativas que exemplificam e reforçam a distância e descontinuidade entre os antepassados (selvagens) e os seus descendentes (civilizados) e de qualificar a "bravura" dos caboclos. Numa destas narrativas sobre a captura de uma tapuia selvagem por um caçador civilizado, é possível, por um lado, explicitar uma acepção na qual a ênfase nos componentes "naturais" da "índia tapuia" supõe uma alteridade radical entre Tapuio (índios selvagens) e Tupi (índios civilizados) e, assim, entre natureza e cultura.

As narrativas expressam uma interessante apropriação dos Potiguara de um tipo de narrativa muito comum no nordeste indígena para aludir à origem nativa e, portanto, falar de si mesmo - "quem somos nós" - derivando-a da tapuia selvagem que mobilizou o trabalho de fundação do tempo histórico pelo índio caçador - herói civilizador - pautado no processo de se tornar civili- 
zado. Por outro lado, a referida narrativa permite entender a concepção em torno da mata e os sentidos e alterações semânticas percebidas entre as categorias classificatórias "índio brabo", "índio selvagem", "índio puro", "caboco brabo" e as classificações "caboco legítimo", "caboco velho" e "caboco cismado". Essa elaboração remete à construção do Tupi e de seu contraponto, o Tapuia, que quase sempre era definido a partir da negação — o não Tupi (MONTEIRO, 1996). A contraposição Tupi e Tapuia consiste em um recurso que tornava minimamente compreensível a diversidade cultural e linguística que marcava o Brasil indígena. Os tapuias eram tidos como inimigos e "representavam, em síntese, o traiçoeiro selvagem dos sertões que atrapalhava o avanço da civilização, ao invés do nobre guerreiro que fez pacto de paz e de sangue com o colonizador" (MONTEIRO, 1996, p. 16).

O rapto da índia tapuia, por sua vez, reforça o sentido de descontinuidade histórica com esse evento e com a tapuia selvagem. Tal descontinuidade se configura seguindo a ênfase na mistura praticada pelos próprios caboclos e nas tentativas de aproximação ou atração dos "brancos" por meio da afinização. A ideia de mistura é decisiva na compreensão do modo pelo qual os Potiguara se veem em relação ao passado (em descontinuidade com os índios puros e os tapuias selvagens) e ao presente, marcado pela diversidade de pessoas, famílias e experiências.

Para compreender o lugar da mistura nos povos indígenas, é preciso reconhecer que ela foi parte precípua de determinadas políticas do Estado nacional, visando a integração e assimilação dos índios. Não obstante, o modo como os indígenas traduziram tais políticas revela a apropriação da categoria caboclo no intuito de refundar a diferença. É importante lembrar que esta categoria foi criada no contexto da política colonial, que objetivava facilitar a mistura com índios de outras etnias. Com a política pombalina do século XVII, os casamentos inter-raciais foram fortemente estimulados, além de outras formas de integração com a pretensão de liquidar as terras das aldeias como a fixação de colonos nas aldeias. A mistura desembocaria inevitavelmente na assimilação e na transformação dos índios em não-índios, destituindo a especificidade dos chamados caboclos pelo esvaziamento da sua condição de "donos originários" da terra, ou autóctones. No século XIX, já foi observado processo semelhante de incorporação por parte das populações indígenas dos aldeamentos do Império como instrumento de diferenciação, a despeito da concepção original de tais equipamentos enquanto máquina de aculturação. A ênfase que os nativos deram foi menos na "aculturação" e "perda cultural" do que nas possibilidades de uma socialidade diferenciada de populações nativas que tinham histórias compartilhadas nestes equipamentos do Estado voltados para os índios. A categoria caboclo sintetiza, portanto, o sentido de uma pureza, por ser 'legítimo', dado a sua bravura, o seu ser arredio e de uma mistura que mantém sua tradição e a transforma em níveis de contato supralocais (interaldeias, interétnico, inter-regional).

A posição e oposição deslindadas nas narrativas em que enfatizam as descontinuidades históricas e culturais justificam o sentido das disputas reverberadas nas cantigas do toré entre os caboclos/índios misturados e os índios tapuios. Há uma semelhança da Florzinha com os Encantados do brabio, os da caatinga, em oposição aos dos fundos dos rios, que são agenciados no toré tumbalalá (ANDRADE, 2008), especialmente, porque correspondem aos antigos índios selvagens e, portanto, não amansados. Ao contrário do investimento dos Tumbalalá em relação aos brabios como "[...] prova da pertença ao seu universo ('todo caboclo é índio', logo, 'eu sou do brabio')" (2008, p. 253, grifos do autor), a Florzinha é pensada, nesse contexto, por meio da necessidade de estabelecer rupturas e descontinuidades. 
O mesmo movimento pode ser identificado entre os Kiriri. Como mostrou Nascimento (1994), os encantados se assemelham à caracterização do "gentio brabio" (aparência de homens descomunais, ferozes e implacáveis, de feições rudes e olhos esbugalhados, verdadeiramente assustadores) que são os antepassados que ainda viviam no mato, e embora não sejam, em princípio, equacionados com esses últimos. A despeito disso, os encantados são prestativos e comunicam-se com os kiriri "na camarinha do Toré, mas também na ciência do índio e em sonhos" (NASCIMENTO, 1994, p. 14, grifos do autor).

Apesar de invisíveis, os encantados assumem formas humanas ou animais durante as experiências oníricas e, no mundo empírico, efetivando a semelhança com os humanos (os não encantados), por terem igualmente corpo e espírito. As experiências oníricas são relevantes para pensar uma das formas recorrentes de revelação dos encantados, como também um dos modos pelos quais, os mestres, ou os pajés, entram em contato com o mundo encantado. Como sugere Langdon (1996, p. 29), "O xamã interage com essas energias por meio da experiência estática, através dos sonhos, ou dos transes induzidos por substâncias ou outras técnicas, servindo como mediador entre os domínios humano e extra-humano".

O sonho, a dança, o canto e outras técnicas promovem a interação com outros domínios, e assim, proporcionam aos especialistas atingir a mediação xamânica, revelando a potência de quem transita entre os mundos e as possibilidades de interpretação deflagradas pelos trânsitos. Como afirma Bastide (2006, p. 128, 133), “o sonho nunca é apenas sonhado, ele é interpretado no despertar, e interpretado mediante a cultura do grupo do sonhador [...] o sonho se alimenta do mito, o mito, reciprocamente, se alimenta do sonho".

Ainda que apresentem feições distintas, os reinados da água e da mata estão situados, enquanto alteridade radical indígena, e convergem no campo das atitudes hostis, dado sua natureza arredia e cismada, e de amizade assumida por seus "donos". Como sugeriu Andrade (2008) para os encantados tumbalalá, é incompatível concebê-los pela chave da dualidade moral (ser bom ou ser mau) e a partir da qualidade desses seres sem levar em conta a "natureza do xamanismo enquanto rito e pensamento, visto que encerra tanto práticas de cura e apoio quanto de agressão" (ANDRADE, 2008, p. 256).

Como mostra Neto (2011), para o contexto dos Atikum, alguns encantados passaram pela experiência da morte, sendo eles os antepassados mais distantes, ou até mesmo algumas pessoas da aldeia que possuíam a "ciência do índio" e que lutavam pelos direitos e cultura dos Atikum. Ele menciona o encantamento de duas pessoas: uma que havia sido assassinada na década de 1990 e a outra, um ex-pajé, que havia morrido afogado em um açude, mas que o motivo do afogamento teria sido o fato dele ser "levado" por outro tipo de encantado, a Mãe d'água.

Nos exemplos registrados em campo, foram comuns relatos da ação dos encantados. A partir da identificação de que os encantados se "engraçam" de alguém, as pessoas dizem que a pessoa foi "flechada" (pelo olhar) por um encantado, como a mãe d'água. A sedução, revelada através de sonhos ou de rezadores, é uma das principais maneiras desse encantado afetar as pessoas, como aconteceu na aldeia Laranjeira, quando uma criança foi "flechada".

Segundo o relato da tia que estava cuidando da criança no momento da "flechada", sua irmã pediu para que não a levasse ao rio, pois havia tido um sonho em que a mãe d'água revelava ter "se engraçado" dele. Contudo o menino teve momentos de choro intenso e o corpo ficou "molhado de suor", então a tia levou-o até o rio. Ele chegou a sua residência com uma intensa febre. 
A mãe procurou um especialista, ou seja, uma rezadeira. Ao iniciar o trabalho, a mãe d'água "manifestou-se" na rezadeira, com uma voz estranha, dizendo que o menino havia sido "flechado", em seguida, ela saiu e veio um mestre que confirmou que a mãe d' água era a "dona" da criança, só que ela não iria levá-lo. Outra vez, a mãe d' água "baixou", dirigiu-se ao menino, tirou uma pena azul de seu umbigo e disse que aquela pena era sua "flecha".

Quando os encantados "se agradam" de alguém e leva-a para seu reinado, o corpo da pessoa passa por modificações. Foi o que ocorreu num caso narrado na aldeia São Francisco. A "flechada" de uma criança deu-se da seguinte forma: o pai da criança fez um pedido à mãe do rio que daria qualquer coisa em troca de uma boa pescaria, inclusive uma de suas filhas. Naquele dia, a pescaria foi abundante. Os peixes "oferecidos" pela mãe do rio foram em grande quantidade, vindo a encher vários cestos. Depois de deixar os peixes em casa, ele conduziu a filha ao rio e concluiu a oferenda. Na ocasião, a mãe da criança que a estava procurando, desconfiou da quantidade de peixes trazidas por seu marido e se dirigiu ao rio, impedindo que sua filha fosse jogada na água. A criança chegou em casa com febre e uma forte dor de cabeça. Levaram-na para um rezador. Ele analisou o estado da menina e disse que já era tarde e que ela já pertencia ao reinado da mãe d'água. No outro dia a menina morreu. Quando foram enterrá-la, as pessoas se surpreenderam com o odor de peixe dentro da casa, olharam para ela e disseram que aquela menina "nem parecia gente", já que se encontrava com um corpo diferente, pois o rosto já apresentava algumas escamas e os olhos já estavam avolumados, como os de um peixe.

A concepção de "flechada" remete a uma ação perigosa que pode transformar a pessoa. Destarte, o contato com os encantados e os espíritos pode ser visto pelo viés da predação, na medida em que envolve a busca pelo diferente para assim refundar a diferenciação através do compartilhamento de corpos assemelhados. Em vista disso, as negociações com os encantados exigem a necessidade de trato e simpatia para conseguir pescarias e caçada abundantes. Nesse caso, o estabelecimento de uma relação de proximidade ou de troca, ao invés de uma relação baseada na identificação, pois "é de outro mundo não sendo, não é povo como a gente, é encantado". O não sendo indica a possibilidade de o encanto deixar de existir quando alguém consegue "flechá-lo", uma vez que "perde o sangue e fica civilizado", isto é, torna-se um igual, assumindo outro ponto de vista e outra forma corporal idêntica ao humano. Essa é a possibilidade de reversibilidade dos seres invisíveis, efetivando o pressuposto de classificação dos encantados como seres selvagens, não domesticados.

Ora, como atingir um encantado com uma "flecha"? A resposta pode ser dada justamente porque os seres invisíveis "se viram" em peixe, em moça, no caso da mãe d' água (reinados do rio e do mar), em peixe e crustáceo, como ocorre com o pai do mangue, e em tatu, coelho ou veado, como a mãe da mata. É interessante notar que na visão dos não-índios, que moram nas aldeias, os encantados, em geral, não se transformam em pessoas ou em bichos.

Sobre a transformação, Langdon (1996) assinala que o poder xamânico está ligado ao sistema de energia global, em que um princípio de transformação suscita a eterna possibilidade das entidades do universo se transformarem em outras e os espíritos adotarem formas concretas, humanas ou animais e os xamãs tornam-se animais, ou assumem formas invisíveis como a dos espíritos e age como mediador, em benefício de seu povo. A comunicação ensejada permite, de um lado, compreender o ritual como instância de comunicação e ato de conjunção de diferenças (humanos e não humanos) e, de outro lado, perceber o xamanismo como um sistema de "comunicação mediadora" (SZTUTMAN, 2005), onde o xamã transita em um espaço que pode ser chamado de "cosmopolítico" permeado por relações multilocais em esferas sociopolíticas. 
Em razão dos encantados poderem "flechar" as pessoas, as experiências descritas apontam para a definição da natureza do perigo no contexto do contato com esses seres invisíveis. Em muitas situações, as pessoas se recusam mencioná-los, porque envolve "coisa ruim" e "eles podem escutar" e, em último caso, chegam a negar sua própria existência. Corrobora-se, assim, a concepção de que o trânsito para o mundo invisível dos reinados é algo extremamente perigoso. Caso alguém acompanhe os encantados e entre em seu reinado, dificilmente voltará. Há o risco de se transformar em um deles, sobretudo, se provar seus alimentos, o que implica na produção de corpos (ou espíritos) aparentados, de maneira especial, porque o compartilhamento de comida supõe comer com e como alguém e, deste modo, participar de sua posição como sujeito dotado de agência. $O$ especialista é capaz de não se deixar seduzir, pois ele é alguém que "entende", no sentido de compreender o lugar e o ponto de vista, ou como sugere Nascimento (1994, p. 13, grifos do autor), "o significado da glossolalia das manifestantes em transe, ou receber mensagens dos encantados em sonho ou mesmo em estado de vigília". Ao se transformarem e se apresentarem sob a forma animal, apenas as pessoas que têm a "ciência" - os especialistas - podem reconhecê-los sob esta forma, distinguindo-os dos simples animais.

\section{ESPECIALISTAS RITUAIS E CORPORALIDADE}

Os especialistas rituais administram as relações entre humanos e não humanos, assumindo um papel importante na interlocução, enquanto um mediador ou um tradutor. Sua ação implica em um modo de conhecer a partir do ponto de vista do outro, cuja interpretação é julgada pelo que consegue ver cada evento como uma ação, uma expressão de estados ou predicados intencionais de algum agente (VIVEIROS DE CASTRO, 2015).

Ao mesmo tempo em que cruza deliberadamente as barreiras corporais, o especialista age no intuito de um estado alterado de consciência que permite visões, através das quais "espíritos ou forças sagradas, de animais, seres da natureza, espíritos guardiões conferem um poder sobrenatural diretamente a pessoa vidente" (AMARAL, 2001, p. 56).

A partir da relação imediata e permanente com o mundo não humano que implica na mudança do próprio corpo, os especialistas rituais podem experimentar o ponto de vista das entidades com as quais mantêm aproximação. A repercussão disso pode ser percebida na fixação da alteridade de tais especialistas no corpo, podendo ser acessado: pelas marcas corporais, como ocorre, por exemplo, com dois especialistas rituais, classificados pelos indígenas como catimbozeiros (residentes no território potiguara), os quais são bastante procurados pelas pessoas que residem nas aldeias e possuem deficiência física e cegueira parcial; e pelos mecanismos processados por ocasião da morte, sobretudo, pela dificuldade do espírito em se separar do corpo ${ }^{6}$.

São representativos os elementos presentes nas narrativas a respeito de dois homicídios sofridos por especialistas rituais no território Potiguara, sendo um considerado "branco" e o outro indígena. Um deles foi morto com golpes de machado e o outro foi esquartejado e queimado. Os dois acontecimentos foram lidos como um sinal de "desgraça" e do destino traumático de todos eles. Em ambos, as justificativas apontaram para acusações de que os "trabalhos de cachimbo", como são classificadas as práticas rituais de catimbó, contribuíram para o crescimento do número de conflitos entre as famílias da aldeia, o aumento das desconfianças entre as pessoas (vizinhos e parentes), gerando intriga e "olho 
grande", e as suspeitas de que as doenças e que acometiam as pessoas eram provocadas por eles.

As versões indicaram que o homicida, do primeiro caso, surpreendeu-se com a dificuldade de matar sua vítima. Apesar dos vários golpes, ele ainda conseguiu chegar com vida a um hospital em João Pessoa, e só faleceu depois de uma semana. A dificuldade de o espírito sair do corpo foi percebida, segundo a concepção, de que todo catimbozeiro é "duro de morrer", uma vez que seu corpo é diferente, pois "incorpora", e o espírito demora a abandoná-lo porque está protegido pelos encantados. Após a morte seu espírito fica vagando no mundo dos vivos como ser do mal.

O outro catimbozeiro foi vitimado por um genro com golpes de foice devido à inveja. Ao contrário do caso anterior, essa morte ocorreu rapidamente, já que seu corpo foi inteiramente destroçado em pequenos pedaços, depois amarrados em uma rede e, em seguida, queimados. A desintegração e a incineração do corpo aceleraram a saída do espírito para o espaço etéreo.

As duas situações descritas trazem elementos que reforçam o argumento desenvolvido no tópico anterior quanto a diferenciação entre o encantamento e a morte e apontam para o lugar de liminaridade e especificidade do corpo do especialista ritual, notadamente dos catimbozeiros. A morte, como vimos, provoca a dissolução do corpo e as práticas espirituais a ela associada são classificados como cultos não indígenas. Os dois homicídios promoveram uma ruptura involuntária do corpo, e revelaram a singularização dos corpos em termos de materialidade ou de substância devido a proteção dos encantados e das práticas rituais de transformação que eles oficiavam.

O corpo dos especialistas indica sua qualidade diferencial vinculada a sua condição de alteridade, especialmente, porque eles estabelecem comunicação com os encantados e, também com os espíritos desencarnados, visando à realização de cura e agressão. Seu corpo simboliza a natureza dos encantados, com os quais essas pessoas estabelecem relações efetivas, como recebê-los em seu próprio corpo por meio da possessão.

Os especialistas assumem uma posição que implica riscos, na medida em que são incorporados por completo, ou seja, no corpo e no espírito, e com isso, age como os espíritos através da "flechada" e da transformação em bicho. Tanto os espíritos desencarnados como os encantados continuam agindo como agentes dotados de vontade e autonomia em relação aos humanos, a quem estão associados por prestações mútuas, que podem desembocar em disputas, já que alguns espíritos se tornam inimigos a partir do agenciamento do catimbó.

As práticas e as agências acionadas no catimbó repercutem diretamente numa ética potiguara em torno da qual a relação com os não humanos é mediada pelos riscos do infortúnio e pela possibilidade de olhar para o outro e de precisar assumir tanto a posição como a visão dele. Entretanto, o que torna uma pessoa mais vulnerável é, sobretudo, olhar para o encantado, pois a pessoa priva-se do próprio olhar e é dominado pelo poder do olhar de encantamento e de sedução, isto é, pela subjetividade e pela agência do outro.

Assim, os especialistas, que incluem também rezadores, ao desenvolverem certas habilidades de "ver", conseguem transitar, olhar e enfrentar os encantados, mesmo correndo o risco de assumir seu corpo e seu ponto de vista. Se esses seres encantados promovem predação e se o controle é realizado, principalmente, pelos especialistas, notadamente os chamados catimbozeiros, a concepção potiguara a respeito deles só pode ser apreendida a partir das acusações de malefícios, que reforça a associação dos encantados à noção de perigo, ao invés da realização de curas. Os catimbozeiros tiram a "flecha" das 
pessoas vivas, mas não "flecha" os encantados, ao contrário, ele fala com eles, tem simpatia, mas não necessariamente os modifica. Logo, "ser catimbozeiro" é possuir uma habilidade ou uma capacidade para lidar com humanos e não humanos, mas também é uma maneira de agir por meio da predação.

Essa é uma das razões pelas quais as pessoas relutam em reconhecer ou admitir que procuram os catimbozeiros para reparar infortúnios e o uso do termo catimbozeiro consistir numa forma de agressão e um desqualificador moral. As pessoas costumam explicar os infortúnios pelas acusações de que foi "flechado" pelo catimbó e que possuem habilidades, disponíveis para todos, para lidar com seres invisíveis.

De maneira particular, os rezadores são acessados para a cura de problemas não resolvidos com tratamentos domésticos como dores no corpo, febre, "espinhela caída", "ventre caído", "mau olhado", íngua, "terçol", "cobreiro" (herpes zoster), quebranto, picadas de bicho (especialmente cobra) e "flechada de catimbó", o que supõe, em alguns casos, a consulta aos chamados catimbozeiros, embora alguns rezadores também acionem o catimbó em seus trabalhos. Além disso, as pessoas preferem procurar pelos rezadores a se submeter ao tratamento médico. Eles dispõem de procedimentos terapêuticos, os chamados benzimentos, que acionam um tipo de conhecimento, a respeito de propriedades curativas de plantas, animais e minerais e são praticados por rezas realizadas com o auxílio de "ramos verdes" e, geralmente, acompanhadas pela prescrição de banhos, chás e compostos feitos à base de ervas medicinais e mel (conhecidos como lambedores), dentre outros. Em todas as atividades, os procedimentos são oferecidos gratuitamente, só que é comum o cliente oferecer algo em troca.

Os catimbozeiros, além de dispor dos mesmos procedimentos dos rezadores, diferenciam-se deles, em primeiro lugar, por estarem situados num plano relacional de maior distância e são, em geral, tidos como "de fora". Em segundo, por acionar nas suas práticas as entidades do catolicismo (santos) e das religiões afro-brasileiras (como mestres e caboclos), o que decorre o uso pejorativo do termo catimbozeiro, frequentemente aplicado às pessoas que lidam com espíritos que compõem o panteão afro-brasileiro. E, por fim, pelo fato deles dialogarem com os encantados através de viagens e/ou os incorporarem por meio de melodias, que são chamamentos para "fazer o trabalho", de orações fortes e do uso da defumação com fumo, diferentemente dos rezadores, que prescrevem banhos e medicamentos à base de mel.

Ao lado dessa compreensão, é comum a afirmação de que "todo índio é catimbozeiro" porque tem olho grande e inveja, sugere que, no limite, ninguém é catimbozeiro, apenas são acusadas enquanto tal. Ao assegurar que "todo índio tem catimbó", sugere-se que tal propriedade está distribuída entre todas as pessoas. Os índios possuem a capacidade de se apropriar das qualidades dos cosmos, através de simpatias ou de experiências oníricas. Porém, ninguém se aventura a se auto afirmar publicamente como possuidor dela, nem se diz catimbozeiro sob pena de ser acusado de trabalhar com feitiçaria. Se uma pessoa tiver alguma experiência onírica com os seres invisíveis, tal sonho sugere um indício de que ela está fortemente associada à feitiçaria, pois como destaca Fausto (2001), ao vê-los é possível controlá-los e se os controlam é sinal de que eles estão sendo utilizados.

Reforça-se a ideia sugerida por Grünewald (1993, p. 73, apud NETO, 2011, p. 59) acerca da "ciência do índio", que seria "um corpo de saberes dinâmicos sobre o qual se fundamenta o segredo da tribo. São saberes de caráter sagrado, de acesso restrito e proibidos a não-índios ou mesmo a índios de outros grupos étnicos" e que, ao mesmo tempo, indica trata-se de um saber de ciência específico que pode ser acionado individualmente. 
A guerra estabelecida com as entidades do catimbó representa um combate contra a suscetibilidade humana à inveja e ao temor a ela associado. Ter "olho grande" significa pôr mau-olhado e este é um dos infortúnios mais comuns, que explicam o motivo pelo qual se procura um rezador para ser curado, ou um catimbozeiro quando se deseja além da cura, a vingança.

Assim, é possível discorrer sobre a negociação com os encantados implicada na predação contra outros humanos na forma de catimbó (ou feitiçaria) à maneira de uma guerra invisível através do ritual do toré, como delinearemos a seguir.

\section{O TORÉ E A GUERRA (IN)VISÍVEL}

A literatura etnológica tem apresentado, nos últimos anos, análises importantes e centrais para o entendimento e compreensão do ritual do toré entre os diversos povos indígenas do nordeste brasileiro. Não é o objetivo aqui fazer um percurso exaustivo sobre tal literatura, mas recuperar aspectos centrais do toré para tentar costurá-los com as interpretações acerca do catimbó dentro do universo das religiões de matriz afro-ameríndia. O interesse é propor uma interpretação que abranja o contexto da ação ritual e a esfera de atuação do que definimos como xamanismo potiguara, enquanto instância mediadora ligada a uma ação sociopolítica.

Antes de adentrar na análise propriamente dita, é importante salientar que o ritual do toré entre os Potiguara, segundo a tradição oral ${ }^{7}$, remonta $o$ "tempo de antigamente", que compreende o tempo "troncos velhos". Nas narrativas, é comum as indicações de que os "troncos velhos" realizavam rituais no meio da mata, nas furnas e neles eram acionados diferentes conhecimentos e habilidades no trato com os animais, com os espíritos e com os encantados. Os rituais de cura e os atos divinatórios são lembrados e mencionados como indícios da capacidade ritual dos indígenas em lidar com doenças, com atividades cotidianas de caça e pesca e com atividades políticas.

Um dos primeiros registros sobre o toré entre os Potiguara foi feito em 1938 pela equipe das Missões de Pesquisas Folclóricas do Departamento Municipal de Cultura de São Paulo9. Como mostra Carlini (1994, p. 130), a equipe foi atraída para Baía Traição/PB pela existência do toré "que não passava de um coco de praia dos índios descaracterizados que moram nas redondezas". A equipe visitou a aldeia São Francisco e registrou um grupo composto por quatro instrumentistas - caixa, reco-reco, privâna (flauta) e bombo -, e gravaram três melodias de toré e uma de cabaçal, em um disco e um lado de disco de doze polegadas. A afirmação de que o toré, "que não passava de um coco de praia", era praticado por "índios descaracterizados" revela, de um lado, o viés culturalista dos integrantes da Missão, a ser aplicado no exame e análise do folclore; a música era, sobretudo para Mário de Andrade, o principal elemento do nosso folclore e o objetivo era registrar e salvaguardar manifestações que corriam risco de acabar por conta de diversos fatores. E de outro lado, aponta para certa semelhança entre o toré o "coco de praia", que ainda é muito comum entre os Potiguara. A despeito de tal visão, a equipe expressou em outras anotações das cadernetas de campo em que se afirmava que tentou "cinematografará e gravará os 'Torés', dança religiosa e guerreira dos índios que ainda existem naquela parte do território desse Estado do Sul" (CARLINI, 1994, p. 81) e o Toré enquanto "manifestação folclórica" (CARLINI, 1994, p. 83). Assim, o toré foi definido como uma dança indígena e uma manifestação folclórica. 
Moonen e Maia (1992), Palitot e Souza Júnior (2005) apontam para outro registro sobre festas e manifestações culturais em 1913 feito por Alípio Bandeira, que era funcionário do Serviço de Proteção ao Índio (SPI). No relato transcrito por Moonen e Maia (1992), o funcionário afirma que nas festas domésticas, nota-se o "apego dos Potiguaras aos seus hábitos ancestrais. Eles dançam e cantam como índios. Usam instrumentos de música, mas instrumentos indígenas" (MOONEN; MAIA, 1992, p. 85-86), como o 'zambê' e o 'puita' que acompanham suas canções e seus sambas. Alípio Bandeira (MOONEN; MAIA, 1992, p. 85-86) continua afirmando que o zambé "é um cilindro oco, fechado nas duas extremidades por couro curtido, no qual tocam com os dedos ou com baquetas. É um bombo alto". Por sua vez, o puita é um cilindro oco fechado no fundo com couro e tendo no centro uma haste de pau com um buraco na parte inferior, por onde se prende ao couro". A haste que é utilizada no puita fica "bamba e a execução consiste em friccioná-la com um pano molhado, o que produz um som cavo e fúnebre". Ele trata a música como "elementaríssima [em que os índios] folgam noites inteiras, dando a quem os contempla, a impressão de um rito bárbaro em plena selva"

Para os Potiguara, o toré é definido como uma "brincadeira" em que se misturam diversão, alegria, respeito e reverência ao sagrado e ao mundo dos encantados, num contexto composto pela diversidade de cores, de traços das pinturas corporais inspiradas nos animais como os peixes, pássaros, tatus, etc. ${ }^{10}$, e de colares de sementes (e mais recentemente, de miçangas) e de plumagens. O toré é também uma linha de trabalho de mestres e de caboclos encantados, cuja ideia de 'incorporar' diz respeito, acima de tudo, ao fato do encantado "se encostar" e agir ("trabalhar"). A incorporação espiritual é reprovada por alguns participantes ou não do toré, sob o argumento de que o toré atua como mecanismo de controle de interferência de "inimigos" que querem desorganizar as pessoas e a própria "brincadeira". Procede daí a concepção de que é indispensável "trancar as correntes para brincar o toré".

A classificação como brincadeira remete a realização do ritual em um contexto de descontração, marcado pela alegria e espontaneidade, especialmente, em espaços públicos, denominando-se comumente de "representação da dança". A brincadeira ou diversão articula-se à ideia de trabalho, que remete à noção de sagrado, tendo em vista que a representação envolve preparação espiritual para execução de certos atos a fim de que sejam evitadas as incorporações de encantados em público. Algumas linhas tidas como fortes, por potencializar o contato com os espíritos e os encantados, não são cantadas nos rituais realizados em espaços externos, fora das aldeias e mesmo dentro das aldeias, como as escolas, em que se evita a incorporação espiritual. Nascimento (1994) mostra que entre os Kiriri, assim como outros grupos indígenas do Nordeste, a diversão e o sagrado não implicam em contradição e revelam a maneira inventiva de articular manifestações e práticas de modo complementar.

Como mostrei alhures, nos momentos festivos, como na "brincadeira do toré", o consumo de bebidas, como por exemplo a cachaça, está frequentemente associado ao "beber com mais gente" e opera como indicador de uma prática relacional alargada, na medida em que envolve momentos de convivência, conversação e relacionamentos. Assim, compartilhar bebida manifesta a positivação da vida em sociedade. A ingestão de cachaça e de outras bebidas alcoólicas atua na construção de vínculo social e se constitui numa manifestação importante de sociabilidade inter e intragrupal. As pessoas ligam as bebidas ao sagrado, ao divertimento, à reciprocidade e, em certos casos, à política.

No toré, por exemplo, o uso da cachaça e outras bebidas, como o "pau do índio" 11 , torna as pessoas capazes de agenciar e serem também agenciadas por seres invisíveis, tais como os encantados, mestres e caboclos, que direta- 
mente se relacionam com o universo de crenças das religiões afro-brasileiras. As "linhas" e a beberagem frequentes deixam os participantes da dança mais vulneráveis, devido à "abertura do corpo" ${ }^{12}$ provocada pela bebida, na medida em que esta deixa a pessoa "fora de si", podendo, assim, ser agenciada por espíritos. O valor do corpo se expressa na potencialização da comunicação entre as pessoas e os espíritos quando o corpo se abre e permite, por meio da ciência da jurema, produzir o trânsito por lugares encantados, pela terra e pelo mar, e como afirma Amaral "[...] em ser Encantada, folha e flor, Mestra, vinho e fumo, cura e punição" (AMARAL, 2009, p. 03). Essa mesma jurema possibilita "[...] trazer de volta os Tupinambás para guerrearem contra o mal, o rei Salomão para aconselhar, os Mestres e Mestras Encantados, que transitam entre o bem e o mal, para curar com suas ervas." (AMARAL, 2009, p. 03).

É o que observamos em algumas linhas do toré Potiguara:

Quem pintou a louça fina foi a flor da maravilha

Pai e filho e espirito santo / filho da virgem Maria

Eu bem disse à laranjeira que ela não botasse a flor

Ela passa sem laranja eu também passo sem amor

Os Potiguara estão rezando apresenta nosso irmão

Me dê força Deus Tupã com meu seis Salomão

Jurema, oh Jurema, minha Jurema, Jurema

Somos as caboca de pena, filhas de Tupinambá

As formas de lidar com o invisível, como descritas acima, aliadas aos predicados dos encantados e dos "donos dos reinados" 13 repercutem significativamente nas concepções e práticas nativas ligadas à esfera ritualística, especialmente, no toré. Neste, há o envolvimento do catolicismo, através das referências aos santos e outras entidades cristãs e dos cultos afro-brasileiros, como o catimbó. Dado o limite tênue entre rezadores e catimbozeiros, cujo índice de diferenciação ou de alteridade, como vimos, pode ser verificado no corpo, no toré, a figura do mestre, tido como "dono da brincadeira", também passa pelo questionamento sobre a natureza do seu corpo e a forma de agenciar os espíritos.

$\mathrm{O}$ referido limite entre os especialistas (rezadores, catimbozeiros e mestres do toré) supõe a distância entre os dois sistemas: o toré e o catimbó. Entendo-os como parte integrante de um mesmo complexo xamânico representado pelo toré, que funciona paralela e transversalmente na política dos humanos e chega em determinadas situações a se cruzarem. As conexões entre o toré e o catimbó e a associação deste último com a feitiçaria são dados principalmente pela operacionalidade de sinais ou de elementos presentes em ambos como: a concepção de encantamento, enquanto processo que envolve, sobretudo, disputas por perspectivas, e a dupla pertença de entidades como "caboca de pena", "caboco velho", "caboquinha da jurema" e a jurema, que é elemento central da cosmologia indígena do nordeste, por possibilitar o estabelecimento de contato com o mundo dos encantados.

Circula uma leitura entre os indígenas que ora acentua a identificação de ambos, segunda a qual o toré é catimbó por ter linhas, mestres e por acionar a jurema como força para o ritual, ora realça a distinção de que o toré é a "religião" ou a "cultura" do índio e o catimbó é uma expressão religiosa dos negros e "brancos". O toré é acionado como marcador de fronteiras simbólicas, daí a necessidade de separá-lo das práticas rituais existentes, especialmente do catimbó que é continuamente associado à feitiçaria e à religião dos negros. 
O temor e a discrição em torno das práticas rituais do catimbó são marcantes nas narrativas e no modo como cotidianamente as pessoas se referem à esfera dos encantados e os tratos com os seres invisíveis. Moonen e Maia (1992) destacaram que os Potiguara não gostam de falar sobre o catimbó e que embora as práticas rituais tenham sido, em grande parte, abolidas ou esquecidas, as crenças no catimbó persistem. Segundo eles, o receio e o esquecimento decorreram significativamente do contexto de perseguição violenta dos cultos de origem africana e indígena por parte do governo da Paraíba ${ }^{14}$.

Ao lado do contexto de repressão por parte do estado às práticas rituais afro-brasileira e ameríndias, é preciso considerar, a persistência da crença no catimbó, na leitura de Moonen e Maia (1996), e o modo pelo qual os indígenas criam estratégias para tal persistência, como por exemplo, silenciar sobre o tema, que indica o segredo ritual como forma de resistência. O segredo é uma construção coletiva que envolve a relação com o sobrenatural, estando esta experiência ligada direta ou indiretamente com a jurema (SILVA, 2000), marcando e reforçando o sagrado e sua manutenção protegeria os indígenas por parte de eventuais intrusos desrespeitosos (REESINK, 2000). Nascimento (1994, p. 123) aponta também para a conservação das crenças em segredo, "na medida e em função, naturalmente, da persistência dos vínculos étnicos".

O qualificador catimbozeiro é a maior ofensa dirigida aos "mestres do toré". Pois estes se colocam justamente no trabalho de controlar os poderes de outrem (dos espíritos), "trancando as correntes", como forma de garantir a organização das pessoas e da própria "brincadeira". Nos momentos em que participei do ritual do toré em que as pessoas se "manifestaram", observei atitudes de apreensão dos que viram a cena (dançarinos ou não). Os presentes teceram comentários que aquela pessoa não tinha força para "se segurar", já os mestres usaram defumação, imposição de mãos e cânticos, numa demonstração de destreza para "afastar" o espírito da pessoa. A propósito, as "linhas do toré", que orientam toda a performance ritualística, constituem-se como mecanismos que buscam impedir a manifestação espiritual de seres que demonstram um comportamento descontrolado, os quais são ritualmente vistos como coisa ruim, daí a associação de toda possessão com as práticas de catimbó. Há, portanto, uma relação tensa quando a representação do toré desemboca na "manifestação espiritual" e no trabalho com os espíritos e encantados, gerando especulações de que o toré tem se misturado com outras práticas e crenças não indígenas, como o catimbó. Está em jogo a definição do que é ritual ou trabalho de índio em detrimento do ritual e trabalho do branco (espiritismo) ou do negro (catimbó, umbanda, candomblé).

Assim como Andrade (2008) sugere para os Tumbalalá no tocante à relação específica entre o toré o xangô, nos Potiguara, as operações de distanciamento e aproximação, realizadas sobre o toré e o catimbó, recaem mais na interpretação do que propriamente na qualidade do rito.

Aqui sigo a intuição de Andrade (2008) para quem a analogia entre o xangô e o toré, no caso dos Tumbalalá, é a posteriori, e não resulta de um viés sincrético, que supõe a fusão entre os sistemas religiosos indígena e africano no nordeste indígena, pois [...] noções nativas para práticas mágicas africanas vieram a ocupar o lugar pré-existente da agressão do xamanismo [...]. O xangô [ou o catimbó] seria uma transformação ocorrida dentro do próprio xamanismo indígena e, a transformação simbólica da feitiçaria ameríndia para a magia africana, o resultado da relação entre diferentes que, por fatores contingenciais e imperativos, viraram próximos (ANDRADE, 2008, p. 209). Nesse sentido, o acesso aos dois sistemas enseja disputas por práticas rituais mais "puras" ou mais tradicionais, e por performances bem mais convincentes, que passam pela introdução e incorporação de elementos rituais de grupos indígenas nordestinos. 
Por outro lado, é possível considerar, a partir da proposição de Nascimento (1994), que o toré e o catimbó pertenceriam ao complexo ritual da jurema e os contatos com ambos, através de fluxos culturais, permitem aduzir o fato de que condutores de rituais de jurema trabalham com elementos do catimbó ou de outras religiões de matriz africana, seja na composição musical, na performance ritual, seja no uso de substâncias ou bebidas. As mudanças ensejadas nas práticas por meio das trocas rituais, também com outros grupos indígenas, podem ser verificadas tanto no plano ritual, quanto no plano étnico. Portanto, a criatividade e a capacidade de reelaboração cultural dos agentes são marcas desse contexto, que conferem novos significados à representação e aos trabalhos, propiciando aos especialistas, experiências religiosas múltiplas e marcadas por práticas assimiláveis (NASCIMENTO, 1994).

O complexo ritual da jurema perpassa as eventuais fronteiras étnicas que se constroem no interior de um campo de interações sociais no qual os indígenas não são agentes isolados. São promovidas alterações importantes na forma como são apreendidos e agenciados os encantados e os mortos e é ampliada as concepções sobre os não humanos.

Em 2007, participei de um ritual do toré na aldeia São Francisco dentro das comemorações do dia do índio. Antes de iniciar a dança propriamente dita, três elementos ganharam notoriedade: a defumação de uma borduna fincada no centro do círculo e das pessoas ali presentes; a invocação dos "Irmãos de Luz", através de um canto dirigido por duas médiuns, no qual foram pedidas proteção e força; e a ingestão de jurema por alguns indígenas, que foi trazida por um dos mestres do toré de um encontro denominado "Terra toré: territorialidade, religião e identidade", realizado nos Pankará na Serra do Arapuá, município de Carnaubeira da Penha-PE, sem propiciar transe mediúnico, ou "manifestação" espiritual.

Quando indagados sobre o sentido da defumação da borduna, alguns mestres e dançarinos do ritual afirmaram que o toré se tornou cada vez mais potente em razão do restabelecimento de práticas como a defumação do terreiro e das pessoas, a introdução de cantos espiritualistas (características da umbanda) e o consumo "restrito" de jurema. Já outros expectadores, apontaram, num certo sentido, para o oposto, uma vez que a incorporação (a "mistura") de algo "de fora" diminuiria a eficácia do ritual. A chave principal de tal avaliação está no reconhecimento de que os indígenas estão aprendendo práticas rituais de outros grupos indígenas, que se aproximaram da religião dos negros, como o catimbó e a umbanda para demarcar uma atitude de resistência.

A repercussão disso no toré pode ser percebida, de acordo com tal visão, na performance da dança e na introdução de cantigas animadas que fazem apologia à jurema aproximando-se dos "trabalhos de cachimbo". Por sua vez, a introdução da jurema se associou as intenções do ritual ao estabelecer momentos lúdicos, daí ser ele uma "brincadeira", e por representar a hostilidade com os "tapuiocanindé". A jurema entra como elemento significativo na economia simbólica da predação, atuando no combate aos Tapuio, e se mesclando, nas cantigas, às "caboca de pena", que constituem uma espécie de encantadas do bem, habitantes das matas no reinado encantado do "juremá" e se opõem aos espíritos do mal, como o dos catimbozeiros.

Na visão de três compositoras do toré (as chamadas irmãs Caranguejeiras Edileuza, Ieda e Zuleide), as "cabocas de pena" sempre revelaram cantigas para o toré e segredos sobre os encantados através de experiências oníricas. Em algumas cantigas, as "índias encantadas", como as "cabocas de pena" são admitidas como filhas de Tupinambá, e deste modo, exprimem uma ideia de ancestralidade, projetam a definição de "índios guerreiros" e produzem um 
duplo distanciamento: em relação aos Tapuio, que se apresentam como encantados da mata, e, portanto, selvagens, e a "caboca de pena", enquanto entidade dos cultos afro-brasileiros.

As pessoas assinalaram a semelhança do ritmo dos passos com os verificados nas rodas de umbanda, bem como na invocação de divindades dos cultos afro-brasileiros, como a "caboquinha da jurema" e a "caboca de pena" e de cantigas que enaltecem a força da jurema. A "caboquinha da jurema" e a "cabocla índia" são invocadas para proteger e ajudar os índios a derrotar os "tapuios Canindé”. Assim, é possível pensar o toré como uma guerra contra aqueles que são vistos enquanto seres descomunais, típico de um espírito/gente selvagem que vagam pelas matas, tabuleiros, grutas ou águas e uma maneira de afirmar a agência dos indígenas civilizados. Ao serem situados na esfera da selvageria, os selvagens (tapuios e as gentes selvagens) ocupam a posição de inimigo, que aciona uma rede de agressões movidas pela feitiçaria ou pelo catimbó, como se verifica em cantigas do toré, já mencionada anteriormente, na qual é lançado o desafio para vencer a "tapuia do canindé" e "amarrar o catimbó".

As leituras dos "mestres" do toré Francisco Vital (que trouxe a jurema de Pernambuco), Sandro (do Forte que atuou na defumação da borduna), Zita (iniciada na umbanda que invocou os espíritos) e Sandro (de Jaraguá, iniciado na umbanda e tocador de zabumba) sobre a introdução de outras práticas rituais no toré apontaram para a necessidade de "limpar" o espaço representado ali pela borduna (concebida como arma de guerra), que estava fincada na terra, cuja intenção era manter as pessoas vinculadas, livrando-as de suas "correntes".

Quanto à ingestão da jurema, argumentaram que ela potencializa o trabalho e protege a "brincadeira" contra as forças dos inimigos, no caso os Tapuio e os catimbozeiros. Para os mestres do toré, os cantos direcionados aos "Irmãos de Luz" objetivaram pedir proteção aos espíritos auxiliares que, diferentemente dos encantados descritos anteriormente, passaram pela morte e se mantiveram próximos aos vivos, os auxiliando. Por outro lado, eles foram inseridos nas práticas e nas representações sobre o encantamento, de acordo com o modelo de gestão com os seres invisíveis, especialmente, com os mortos. Esse modelo se constitui por meio da evitação, do contato e através de experiências oníricas (já apontadas anteriormente) e da relação de trato e simpatia.

O mesmo se observa com relação aos "irmãos de luz", que são lideranças indígenas, mestres do toré e rezadores que se transformaram em encantados e foram recentemente incluídos no domínio dos espíritos, ampliando, assim, a ideia de encantado, deixando mais nítidas as diferenciações entre os mortos. De um lado, estão os "espíritos bons", agora definidos como "espíritos de luz", que são vistos como encantados com quem passam a partilhar experiências cotidianas, conviver, manter proximidade espacial e genealógica. E de outro, encontram-se os "espíritos maus", que são principalmente pessoas praticantes de feitiçaria ou de catimbó e reforçam que a morte trágica dos catimbozeiros, como descrita alhures, é o parâmetro de leitura usado para interpretar o destino dos mesmos e é importante destacar que o uso desse termo é uma tentativa de produzir distâncias genealógicas e identitárias.

A compreensão de morte sugere duas chaves de interpretação. A primeira aciona a concepção do catimbó de que a identidade do mestre não se dissolve com a morte, pois como sugere Bastide (1945, p. 205) "A morte, longe de destruí-lo, dá-lhe mais uma vantagem. Pode ele se transformar em encantado". A segunda aponta à concepção de que o espírito do morto se desprende do corpo e "fica no mundo", ou seja, permanece nos lugares onde viveu e continua a realizar as mesmas atividades, alimenta-se do que estiver ao seu alcance e prefere erva do mato, fruta e mel. A alma peregrinará entre os vivos como 
forma de penitência, por ter praticado algo reprovável, como por exemplo, o catimbó. Os corpos são levados ao cemitério e lá são plantados; sob a sepultura, são plantados galhos de flores como forma de embelezá-la.

Os "irmãos de luz" são definidos como "espíritos bons", e vistos como encantados com quem passam a partilhar experiências cotidianas, conviver, manter proximidade espacial e genealógica. Já os "espíritos maus" são principalmente pessoas praticantes de feitiçaria ou de catimbó que continuam a atuar junto ao mundo dos vivos.

No mesmo toré de 2007 descrito anteriormente, uma cantiga nova foi entoada. Na cantiga exaltava-se a figura do cacique Daniel Santana que tendo descido da serra vestido de pena (como "caboco de pena"), ele era o "cacique da jurema". A atribuição das qualidades de encantamento a Daniel, por meio das referências são "caboco de pena" e a jurema regida por um cacique, explicita a constituição de uma unidade cosmopolítica, que condensa as pessoas em suas práticas político-rituais e as relações com a esfera do sobrenatural-espiritual. Ela induz o movimento de "inclusão" dos mortos no reino dos encantados, dominado por caciques, que são concebidos como os protetores da aldeia, e em vista disso, promove a ampliação da concepção de encantamento (compulsório), enquanto ato de captura, tal como foi verificado nas versões da mãe do mato e da água.

O uso de bebida no toré (mas não apenas), como a cachaça, potencializa as pessoas a estabelecer o contato com os seres invisíveis e a falar com mais abertura sobre os encantados e a morte, por meio das lembranças do passado, evocadas pelos mais velhos, e do contato com os espíritos nas situações de "incorporação". É sobre isso que o toré procura agir, ou seja, prender as correntes porque, como se costuma ouvir dos mestres, todo índio possui uma magia ou um tipo de conhecimento ou sabedoria "que vem da mata, da água, da natureza" (Sandro, mestre do toré, residente de Jaraguá), reforçando a expressão corriqueira, já assinalada acima, de que "todo índio tem catimbó".

A utilização da palavra magia, em analogia ao catimbó, sugere mais uma vez a aproximação entre o toré e este último. Ambos são referenciados a partir dos mecanismos de controle e proteção, que agenciam a "força do pensamento e da oração numa magia só" (Pajé Sandro), e do fato de possuírem as mesmas "linhas", que são os cantos de invocação dos encantados, dadas por estes através de sonhos ou podem ser de autoria pessoal.

No tocante ao sentido de magia, diversos estudos sobre catimbó (BASTIDE, 1945, VANDEZANDE, 1975; CASCUDO, 1978), definido como "magia do nordeste" (RIBEIRO, 1992), indicaram tratar-se: de uma "antiga festa da Jurema, que se modificou com o contato com o catolicismo, mas que, assim transformada, continuou a se manter nas populações mais ou menos caboclas" (BASTIDE, 1945, p. 222); de feitiço, coisa-feita, sortilégio e como prática não religiosa (CASCUDO, 2000) e resultante do encontro das tradições indígenas e africanas e como cerimônias de feitiçaria, sendo a prática do catimbó e feitiçaria paralela ao "adjunto de jurema" (CASCUDO, 1978). São centrais no catimbó nordestino, a jurema e o contato com o catolicismo, a crença na existência de um mundo sobrenatural - outro mundo - povoado por reinos encantados, os quais são dirigidos por "mestres" — que são a entidade espiritual central dos catimbós - os quais individualmente tem uma linha. Os reinados encantados são formados "por chefes indígenas, almas das pessoas mortas, antigos catimbozeiros, espíritos católicos e espíritos negros” (ASSUNÇÃO, 2006, p. 80) e "a linha de cada mestre resume a ação sobrenatural, as excelências do poder e a sua especialidade técnica” (ASSUNÇÃO, 2006, p. 81). 
A defumação para curar doenças, por meio do cachimbo, e o emprego do fumo para entrar em estado de transe são outros elementos constitutivos das práticas rituais do catimbó que exprimem o envolvimento do "mestre" com os processos de cura e representações de encantados e outras entidades espirituais. Como mostra Ribeiro (1992, p. 24), os mestres "são os guias, orixás sem culto, acostando, espontaneamente ou invocados para servir", os quais possuem fisionomia própria, gestos, maneiras diferentes de atuação. É esse catimbó que personaliza espíritos que habitam os vegetais em entidades antropomórficas, os caboclos (VANDEZANDE, 1975).

Alguns dos elementos acima referidos apresentam-se também na prática ritual do toré. A despeito do controle da manifestação espiritual nas apresentações públicas do toré, os transes quando acontecem são produzidos por processos físicos, com fumo e jurema, e o trabalho dos encantados tomando o corpo das pessoas que estão na roda. Os mestres do toré sempre dirigem o ritual com as cantigas, pois "sem canto não há encanto" (CASCUDO, 1978), com os instrumentos musicais e com os cachimbos; além de chupar a fumaça, os mestres sopram com força para fazer defumação do ambiente, dos objetos e dos participantes do ritual. A ciência da jurema, que é praticada por mestres viventes e do além e esses são "donos dos bons saberes" (CASCUDO, 1978, p. 165) e verdadeiros detentores desta ciência, é concomitante com a "Ciência do Cachimbo" (BRANDÃO; NASCIMENTO, 1998, p. 83), a qual é dada através do sopro invertido do cachimbo e este é catimbó e vice-versa (CASCUDO, 1978, 2000). Como sugere Araújo (1961), o toré é o mesmo catimbó, pajelança, sendo denominações de uma dança e de uma cerimônia que variam regionalmente; em Piaçabuçu (Alagoas), o Toré é o mesmo que o catimbó "onde além das funções medicinais fitoterapêuticas são encontrados os elementos fundamentais deste, herdadas do índio: a jurema e a defumação curativa" (ARAÚJO, 1961, p. 76).

Porém, a diferença entre ambos diz respeito à natureza do trabalho: no catimbó, os encantados são chamados a proceder na cura ou na agressão, já no toré, o foco recai na tentativa em bloquear o "catimbó" das pessoas para que os espíritos não sejam atraídos ou se "encostem" nelas e desorganizem a "brincadeira", isto porque a aproximação com tais agências torna as pessoas mais vulneráveis à interferência dos mesmos, por meio da "manifestação" espiritual e da potencialização das habilidades em lidar com o mundo extra-humano. Assim, o controle envolve desde uma batalha contra tais agências, até o estabelecimento de relações de trato e simpatia por meio do toré.

\section{XAMANISMO, RESISTÊNCIA E TRADUÇÃO}

A partir dos elementos acima descritos, é possível identificar uma dupla tentativa no toré, qual seja, estabelecer vínculos no intuito de exercer sobre os encantados um controle e apropriar-se de sua agência, de acordo com uma "política cosmológica de prevenção" (ANDRADE, 2008). Os encantados tornaram-se espíritos com quem os vivos podem contar para a proteção da aldeia e para seu agenciamento nas resoluções de conflitos.

O toré pode ser encarado como um ritual voltado mais para os encantados do que para os mortos, embora a lógica relacional esteja ancorada na tentativa de produzir disjunção com esses seres. Tais movimentos foram feitos a despeito dos encantados não terem passado pelo imperativo da morte. Semelhante aos encantados, os mortos apresentaram uma qualidade diferenciada de corpo e de espírito e passaram a integrar um coletivo delineado pela regência de um "dono", com o qual é possível estabelecer relação de aproximação, mas 
também de distanciamento dada à ruptura provocada pela morte. $\mathrm{O}$ dilema colocado a partir disso é que os mortos, apesar de encantados, descolaram-se do mundo dos vivos, tornaram-se diferentes ao se aproximarem da condição de selvagens, o que justifica a imprevisibilidade de suas ações, tal como ocorre com os encantados anteriormente descritos.

A posição do mestre do toré, assim como dos rezadores e catimbozeiros, sugere sua atuação como uma espécie de "dono", cujo significado semântico recobre tanto o plano sociológico quanto o cosmológico. No primeiro, a palavra recompõe o sentido atribuído aos sujeitos que iniciam atividades, convocam e convidam pessoas para participar de festas, conseguem agregar e manter familiares sob sua proteção e controle, assegurando-lhes bem-estar, e o fato de atrair parentes e não-parentes. Desse modo, são garantidas a reprodução e a mobilidade do grupo doméstico, como também o desenvolvimento de um princípio de autoridade.

Se considerarmos que a ação dos "donos" envolve sempre proteção, controle e cuidados, é inevitável conceber as relações baseadas, sobretudo, nas amizades e lealdades que eles agenciam, como sendo assimétricas, as quais se constituem enquanto uma forma social decisiva na própria configuração do domínio do político. Ainda que suas ações sugiram a produção de uma singularidade, a atualização das diferenciações internas ao grupo não deixa de ser expressa, como pode ser identificadas nos reiterados jogos da política indígena, marcados pelas divisões, conflitos e configuração de grupos políticos distintos.

Os "donos", portanto, desenvolvem uma atividade de tradução e de diplomacia, como sugere Carneiro da Cunha (1998) sobre o xamanismo, o que remete a ideia de maestria como uma nova linguagem que "enquanto mecanismo de produção de pessoas magnificadas, que contém tanto os dispositivos de produção da potência, como os de solapamento do poder" (FAUSTO, 2008, p. 342), é capaz de cobrir um domínio da liderança, ao invés de um campo de dominação (SZTUTMAN, 2012) ${ }^{15}$.

Ao mesmo tempo, identificamos uma reelaboração das concepções xamânicas tradicionais que não estão restritas a um saber cosmológico, mas passam a incorporar e dar visibilidade ao discurso étnico. A ação política propiciada pelo xamanismo revela, de um lado, a resistência à assimilação das práticas tidas como indígenas às práticas e crenças concebidas como de negros (o catimbó, a umbanda e a jurema). E, de um outro, o acionamento de uma linguagem do ponto de vista étnico que possibilita a comunicação interétnica a partir da definição da etnicidade como linguagem (CARNEIRO DA CUNHA, 2014). A escolha dos tipos de traços culturais e de quais traços culturais serão realçados que poderá assegurar e marcar a distinção do grupo depende, em primeiro lugar, "dos outros grupos em presença e da sociedade em que se acham inseridos, já que os sinais diacríticos devem poder se opor, por definição, a outros de mesmo tipo", e, em segundo lugar, "das categorias comparáveis disponíveis na sociedade mais ampla, com as quais poderão se contrapor e organizar em sistema" (CARNEIRO DA CUNHA, 2014, p. 238). Essa visão aproxima-se da proposição de Overing (1990) sobre o xamã como construtor de mundo, em que as formas de construção do mundo são recorrentemente baseadas em verdades parciais, cujas versões estão sempre associadas a marcos de referência. O xamã desenvolve a capacidade de traduzir e interpretar visões de mundo outras, parciais, de modo a tornar inteligíveis os conhecimentos e as percepções através da adoção de uma linguagem que expressa um ponto de vista parcial, suspendendo a linguagem ordinária e ativando o esotérico.

Portanto, o toré pode ser entendido na perspectiva do xamanismo como sistema de comunicação e mediação, dentro do modelo histórico de 
relações sociais, cujo funcionamento responde, dentre outras coisas, pelo cuidado das relações estabelecidas com os encantados mais do que uma "espécie de clínica xamânica sem remédios", voltando-se, portanto, para uma "política cosmológica da prevenção" (ANDRADE, 2008). Ao observar o toré potiguara, verifico o trabalho preventivo do toré, tal como sugerido por Andrade (2008) para os Tumbalalá, como também observo uma intenção de gerir a relação com os espíritos dos mortos e dos encantados por meio do amansamento ou de sua domesticação.

\section{NOTAS}

${ }^{1}$ É possível falar da temporalidade dos Potiguara a partir de três momentos: o "tempo muito antigo" que remete a um tempo marcado pela domesticação de uma tapuia selvagem por um caçador civilizado, cujas referências recaem ao um tempo mítico; "o tempo de antigamente" que é o dos troncos-velhos, com os quais há relatos ou testemunhos de compartilhamento de experiências, levando a compreender como um tempo histórico; e o "tempo de hoje" que se conecta a ambos, mas é efeito do processo histórico e político de continuidade pela ideia de autoctonia e de descendência e descontinuidade pela concepção de que são "índios misturados".

${ }^{2}$ Tal concepção se assemelha a do povo Pankararu de Pernambuco, para quem os encantados são os espíritos de índios que não morreram, mas abandonaram voluntariamente o mundo por "encantamento", passando a compor o panteão virtualmente indeterminado de espíritos protetores de cada grupo (ARRUTI, 1996).

${ }^{3}$ Os Atikum diferenciam também os "encantados da terra" e os "encantados do ar" (ou "encantados de luz").

${ }^{4}$ A amesca é uma planta da família da Burseraceae, espécie Protiumicaraiba (DC), que produz um tipo de resina usado pelos mestres do toré para purificar o terreiro onde a dança é realizada. Os Kariri-Xokó de Alagoas utilizam-na juntamente com o fumo e outras ervas para a purificação do corpo material e o encontro com os seres espirituais. Disponível em: https://www.indiosonline.net/historico_dos_xucuru_kariri/. Acesso em: 15 fev. 2019.

${ }^{5}$ Agradeço à sugestão muito apropriada e pertinente do/as pareceristas $a d$ hoc sobre a importância de se discutir as categorias utilizadas no processo de colonização, articulando-as com os termos e categorias nativas a partir de interpretações históricas, étnicas e identitárias.

${ }^{6}$ Usarei catimbozeiro para se referir às pessoas classificadas pelos Potiguara como especialistas rituais, cujas práticas envolvem o uso da jurema, o contato com espíritos e entidades como mestres e caboclos, as manifestações espirituais e os trabalhos com cachimbo, maracás dentre outros elementos. Remete, em alguns contextos, a uma categoria pejorativa, tendo em vista ser acionada na definição de trabalhos com viés negativo, já que supostamente busca fazer o mal às pessoas.

${ }^{7}$ Tomamos a definição de tradição oral de Vansina (2010), que afirmar ser a tradição como história, um testemunho transmitido oralmente de uma geração à outra, formando um elo através de cada narrador, relator ou informante e a oralidade é uma atitude diante da realidade. As tradições orais consistem de todos os testemunhos verbais/orais que são relatos sobre o passado, definição que implica que relatos falados e cantados entrem em consideração na tradição oral.

${ }^{8}$ Os troncos velhos correspondem aos núcleos comuns de antepassados, em torno dos quais ocorreu a composição de famílias, formando a base de uma "comunidade de sangue" ou "comunidade de parentes, cujos descendentes são tratados como "pontas de rama" (no "tempo de hoje"). Do ponto de vista genealógico, os "troncos velhos" correspondem à geração dos avós; há casos, não tão comuns, que incluem os bisavós e os tataravós, parentes de terceira e quarta gerações acima de ego.

${ }^{9}$ Grünewald (2005) assinala que a mesma equipe das Missões registrou a jurema no catimbó.

${ }^{10} \mathrm{O}$ vermelho e o preto são as cores presentes nas pinturas corporais. O vermelho vem do urucum e o negro vem do fruto jenipapo que combinadas com colares, plumagem e modelos de pintura corporal propiciam múltiplas formas de enfeitar, embelezar e construir corpos.

${ }^{11}$ Trata-se de uma bebida produzida artesanalmente, especialmente, por homens, feita à 
base de cachaça misturada com várias ervas, raízes e cascas de árvores. É recomendada ainda a adição de frutas como o caju, a mangaba, dentre outras, por acreditar que com essa mistura, a bebida fica "forte" e deixa as pessoas mais alegres, expansivas, e, sobretudo, viris. Após a mistura desses ingredientes, a garrafa é enterrada por, no mínimo, três dias. Na visão dos preparadores e de grande parte dos consumidores da bebida, a garrafa "fica tampada e a gente enterra, falta o ar e aí ela fica apurada, fica no ponto" para garantir a "força".

${ }^{12}$ A dimensão da corporalidade ocupa centralidade nos múltiplos rituais afro-indígenas no Brasil. Grünewald (2005) indica que os índios do Nordeste "são os depositários da ancestralidade buscada desde as religiões extáticas brasileiras como o Catimbó, a Umbanda e o Candomblé de Caboclo, até pelo experimentadores pós-modernos" (GRÜNEWALD, 2005, p. 240), sendo o índio o "sujeito fundador do conhecimento xamânico sobre a planta e sua bebida" (GRÜNEWALD, 2005, p. 240). Por outro lado, a jurema possui uma importância fundamental em formas religiosas como o Xangô e a Umbanda, não podendo ser entendido "como uma forma secundária de religiosidade ou prática mágico-curandeirística” (BRANDÃO; NASCIMENTO, 1998, p. 89).

${ }^{13}$ A categoria "dono" remete a "capacidade de conter — apropriar-se ou dispor de pessoas, coisas, propriedades e de constituir domínios, nichos, grupos" (SZTUTMAN, 2005, p. 261).

${ }^{14}$ A partir da mobilização de povos de terreiro foi aprovado, em 1966, o livre exercício dos cultos africanos pela Lei n. 3443 de 1966, a qual, entretanto, nada especifica sobre os cultos de origem indígena, como o catimbó. A lei vinculava a realização dos cultos à autorização da Secretaria de Segurança Pública e obrigava as casas religiosas a regularizarem seu registro e os responsáveis pelos cultos deveriam fazer prova de idoneidade moral e de 'perfeita sanidade mental', consubstanciada em laudo psiquiátrico. No dia 13 de novembro do mesmo ano, foi criada a Federação dos Cultos Afro-Brasileiros da Paraíba, em João Pessoa.

${ }^{15}$ Fausto (2008, p. 329) salienta que a relação maestria-domínio não pode ser reduzida a uma "simples categoria ontológica, a dos donos ou mestres da natureza".

\section{REFERÊNCIAS}

AMARAL, Leila. Carnaval da Alma. Rio de Janeiro: Editora da UFRJ, 2001. AMARAL, Rita. A fina ciência da Jurema. Ponto Urbe, Ano 3, n. 4, p. 01-06, 2009. Disponível em: http://journals.openedition.org/pontourbe/1738. Acesso em: 05 nov. 2019.

ANDRADE, Ugo M. Memória e Diferença: Os Tumbalalá e as redes de trocas no submédio São Francisco. São Paulo: Humanitas, FAPESP, 2008.

ARAÚJO, Alceu M. Medicina rústica. São Paulo: Companhia Editora Nacional, 1961.

ASSUNÇÃO, Luiz C. de. O Reino dos Mestres: a tradição da jurema na umbanda nordestina. Rio de Janeiro: Pallas, 2006.

ARRUTI, José Maurício A. A árvore Pankararu: fluxos e metáforas da emergência étnica no sertão do São Francisco. In: OLIVEIRA, João Pacheco de (org.). A viagem da volta: etnicidade, política e reelaboração cultural no Nordeste Indígena. Rio de Janeiro: Contra Capa, p. 229-277, 1996.

BASTIDE, Roger. Sociologia do Sonho. In: O Sagrado Selvagem e outros ensaios. São Paulo: Companhia das Letras, 2006.

. Imagens do Nordeste místico em branco e preto. Rio de Janeiro: O

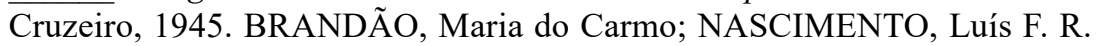
Catimbó-Jurema. Clio Arqueológica, n. 13, p. 71-94, 1998.

CARLINI, Álvaro. Cante lá que gravam cá: Mário de Andrade e a Missão de Pesquisas Folclóricas de 1938. Dissertação. (Mestrado em História), Universidade de São Paulo, São Paulo, 1994. 
CARNEIRO DA CUNHA, Manuela. Etnicidade: da cultura residual mas irredutível. In: Cultura com aspas. São Paulo: Cosac Naify, p. 235-244, 2014.

. Pontos de vista sobre a floresta amazônica: xamanismo e tradução. Mana, v. 4, n. 1, p. 7-22, 1998.

CASCUDO, Luís da Câmara. Dicionário do Folclore Brasileiro. 9. ed. São Paulo: Global, 2000.

. Meleagro: pesquisa do catimbó e notas da magia branca no Brasil. Rio de Janeiro: Agir, 1978.

CRUZ, Henrique A. C. Tapuyas e mestiços nas aldeias e sertões do norte: conflitos, contato e práticas "religiosas" nas fronteiras coloniais (1680-1761). Tese. (Doutorado em História Social), Instituto de História, Universidade Federal Fluminense, Niterói, 2018.

FAUSTO, Carlos. Donos demais: maestria e domínio na Amazônia. Mana, v. 14, n. 2, p. 329-366, 2008.

. Inimigos Fiéis: História, Guerra e Xamanismo na Amazônia. São Paulo: EDUSP, 2001.

GRÜNEWALD, Rodrigo de A. Sujeitos da Jurema e o Resgate da 'Ciência do Índio. In: LABATE, B.; GOULART, S. (orgs.). O Uso Ritual das Plantas de Poder. Campinas: Mercado de Letras, p. 239-278, 2005.

LANGDON, Ester J. M. Introdução: xamanismo - velhas e novas perspectivas. In:__. (orgs.). Xamanismo no Brasil. Florianópolis: Editora da UFSC, p. 09-37, 1996.

LATOUR, Bruno. Whose cosmos, which cosmopolitics? Comments on the Peace Terms of Ulrich Beck. Bruno Latour Common Knowlegde. Common Knowledge, v. 10, Issue 3, p. 450-462, 2004.

LÉO NETO, Nivaldo A. "Na lição da abeia-mestra": Análise do complexo simbólico e ritualístico do mel e das abelhas sem-ferrão entre os índios Atikum. Dissertação. (Mestrado em Ciências Sociais), Universidade Federal de Campina Grande, Campina Grande, 2011.

MOONEN, Franz; MAIA, Luciano M. Etnohistória dos Índios Potiguara: ensaios, relatórios e documentos. João Pessoa, PR/PB - SEC/PB, 1992.

MONTEIRO, John. As 'raças' indígenas no pensamento brasileiro do Império. In: MAIO, M; SANTOS, R. V. (orgs.). Raça, Ciência e Sociedade. Rio de Janeiro: Fiocruz, p. 15-22, 1996.

PALITOT, Estevão; SOUZA JÚNIOR, Fernando B. Todos os pássaros do céu: o toré potiguara. In: GRÜNEWALD, Rodrigo de A. (org.). Toré: regime encantado do índio do Nordeste. Recife: Massangana, p. 187-219, 2005.

MOTA, Clarice Novaes; BARROS, José Flávio P. de. O Complexo da Jurema: representações e drama social negro-indígena. In: . ALBUQUERQUE, U. P. (orgs.). As muitas faces da Jurema: de espécie botânica à divindade afro-indígena. Recife: Bagaço, p. 19-60, 2002.

NASCIMENTO, Marco Tromboni. "O Tronco da Jurema": ritual e etnicidade entre os povos indígenas do Nordeste - o caso Kiriri. Dissertação. (Mestrado em Sociologia), Universidade Federal da Bahia, Salvador, 1994.

OVERING, Joanna. The Shaman as a Maker of Worlds: Nelson Goodman in the Amazon. Man, v. 4, n. 25, p. 602-619, 1990.

REESINK, Edwin. O Segredo do Sagrado: o Toré entre os índios no Nordeste. In: ALMEIDA, L. S.; GALINDO, M.; ELIAS, J. L (orgs.). Índios do Nordeste: temas e problemas - II. Maceió: EDUFAL, p. 315-346, 2000.

RIBEIRO, José. Catimbó: magia do Nordeste. Rio de Janeiro: Pallas, 1992.

SILVA, Christiano Barros Marinho da. Os Índios Fortes: aspectos empíricos e interpretativos do xamanismo Kariri-Xocó. In: ALMEIDA, L. S.; GALINDO, 
M.; ELIAS, J. L (orgs.). Índios do Nordeste: temas e problemas - II. Maceió: EDUFAL, p. 315-346, 2000.

STENGERS, Isabelle. The Cosmopolitical Proposal. In: LATOUR, Bruno; WEIBEL, Peter Weibel (Eds.). Making Things Public: Atmospheres of Democracy, Cambridge MA: MIT Press, p. 994-1003, 2005.

. Cosmopolitiques I: la guerre des sciences. Paris: La Découverte, 1997.

SZTUTMAN, Renato. O Profeta e o Principal: a ação política ameríndia e seus personagens. São Paulo: EDUSP, 2012.

. Sobre a ação xamânica. In: GALLOIS, D. T. (org.). Sociedades indigenas e suas fronteiras na região sudeste das Guianas. São Paulo: Humanitas, p. 151-226, 2005.

VANDEZANDE, René. Catimbó: pesquisa exploratória sobre uma forma nordestina de religião mediúnica. Dissertação. (Mestrado em Sociologia) - Universidade Federal de Pernambuco, Recife, 1975.

VANSINA, Jan. A tradição oral e sua metodologia. In: KI-ZERBO, J. (Ed.). Metodologia e Pré-História da África. Brasília: UNESCO/Ministério da Educação, v. 1, p. 138-166, 2010.

VIEIRA, José Glebson. Amigos e competidores: política faccional e feitiçaria nos Potiguara da Paraíba. São Paulo: Humanitas, USP, 2012.

VIVEIROS DE CASTRO, E. Metafísicas Canibais: elementos para uma antropologia pós-estrutural. São Paulo: Cosac \& Naify, 2015. 